\title{
Musculo-skeletal and pulmonary effects of sitting position - a systematic review
}

\author{
Elżbieta Szczygieł', Katarzyna Zielonka', Sylwia Mętel', Joanna Golec' \\ ${ }^{1}$ Section of Rehabilitation in Orthopaedics, Chair for Movement Rehabilitation, Bronisław Czech University School of \\ Physical Education, Cracow, Poland \\ ${ }^{2}$ Department of Physiotherapy, Faculty of Motor Rehabilitation, The University School of Physical Education in Cracow, \\ Poland
}

Szczygieł E, Zielonka K, Mętel S, Golec J. Musculo-skeletal and pulmonary effects of sitting position - a systematic review. Ann Agric Environ Med. 2017; 24(1): 8-12. doi: 10.5604/12321966.1227647

\begin{abstract}
Introduction. Year after year, we spend an increasing amount of time in a sitting position. Often, we sit with poor posture, as indicated by numerous pain syndromes within the musculoskeletal system. Several reports confirm that body posture and the amount of time spent in a seated position have extensive implications for our health. Previous studies and a literature review suggest there is limited knowledge regarding an ergonomic sitting position.

Objective. The aim of the study was to analyze the research relating to a proper sitting position and the consequences of incorrect sitting posture. A database search was conducted in Science Direct, Scopus, PubMed, Medline, and Google Scholar. Selection was made on the basis of titles, then abstracts and full texts of the studies. No limits were applied to the date of publication.

Conclusions. Incorrect sitting posture contributes to many disorders, especially in the cervical and lumbar spine. It also determines the work of the respiratory system. Most authors suggest that maintenance of the physiological curvature of the spine is crucial for the biomechanics of the sitting position, as well as the location of the head and position of the pelvis. It raises awareness of work-related hazards and the introduction of education on the principles of proper seating. It is necessary to draw attention to the risks associated with work performed in a sitting posture, and education on the principles of ergonomical sitting.
\end{abstract}

\section{Key words}

sitting posture, ergonomic sitting, back pain

\section{INTRODUCTION}

Many of us now spend the majority of our waking time in a sitting position: at school, driving a car, watching TV, and above all, working at a desk and with a computer. Often, our sitting position is

incorrect, as evidenced by the presence of numerous musculoskeletal pain syndromes. Such problems are mostly prevalent among people who spend many hours working with a computer [1]. According to the National Statistical Office, there is constant growth of people owning a computer, and an extensive Internet network favours a drastic increase in time spent in a sitting position. In 1997, the number of hours per week spent in front of a monitor was 5.9 hours, and in $2003-14.6$ hours [2]. According to research from $2012,51-68 \%$ of young people prefer a sedentary life style, $27-44 \%$ include a small physical activity in their free time, and only $5 \%$ have a high physical activity during the day. The sitting position requires only minimal energy expenditure, in an amount of 1.0-1.5 METs [3]. Several reports confirm that the manner and the time spent in a sitting position has extensive implications for our health. Previous research suggests a paucity of knowledge regarding an ergonomic sitting position.

Address for correspondence: Elżbieta Szczygieł, Section of Rehabilitation in Orthopaedics, Chair for Movement Rehabilitation, Bronisław Czech University School of Physical Education, Cracow, Poland

E-mail: elzbietasz@gmail.com

Received: 25 February 2014; accepted: 26 Juny 2014; first published on December, 2016

\section{OBJECTIVES}

1. Literature review and summary of results relating to a sitting position.

2. Analysis of the consequences of incorrect sitting.

3. Characteristics of the correct sitting position.

\section{MATERIALS AND METHOD}

For the purposes of this study, database searches conducted in Science Direct, Scopus, PubMed, Medline, and Google Scholar. The key words used were: sitting posture, chair design, chest wall during sitting, ergonomic sitting, office work. The selection was made on the basis of titles and abstracts and full texts of works. No limits were applied to the date of publication.

The total number of examined people in the analyzed publications amounted to 438 people. Due to the different nature of the research, the age range of the examined participants was very wide, from 18 - 74 years of age.

Measurement methods that were used in the included articles: 3D electromagnetic cracking system, ultrasoundULTRASONIX-ES500, EMG, plethysmograph, pneumotahograf, spirometer, palpation, VAS, X-ray examination, posturography, and range of motion in the joints.

Effects of sitting position on the cervical spine. Office staff are a professional group characterized by sedentary working conditions. Spending many hours in a 'supposedly' 
comfortable position working at the computer with minimal physical exertion, predisposes to the formation of complaints on the part of the musculoskeletal system. This occupational group became the inspiration for the design and construction of seats, favouring the adoption of physiological posture and movement while ensuring static 'activity' $[2,3,4]$.

Some of the most common symptoms reported by office workers are headache and neck pain with referred pain to the upper limb $[5,6]$. Szeto indicates the causes of these symptoms as long-term muscle tension of the neck and shoulder muscles, which stabilize the head during excessive neck bending. This is not only a burden for soft-tissue structures, but also for the joints of the spine, especially in the cervical-thoracic junction [4].

Both Jung-Ho [2] and Groszek [4] claim that a constant position with excessive neck bending causes upper cross syndrome, characterized by weakening of the deep muscles of the neck, rhomboids and serratus anterior muscles, and hypertension in the pectorales and upper trapezius muscles. According to Janda's Classification of Muscle Imbalance Patterns, weakness from muscle imbalance results from reciprocal inhibition of the tight antagonist [8]. The degree of soft tissue tension, emphasized by Caneiro [9], is largely dependent on the sitting posture. The researcher described three types of standardized thoraco-lumbar sitting postures: lumbo-pelvic, thoracic upright and slump. He estimated the correlation between the most commonly used sitting positions and muscle activity, and concluded that sitting in a slump position significantly increases tension in the neck extensors, as well as the pectoral muscles, as a result of anterior head translation. Furthermore, this position increases neck flexion, thereby reducing lower cervical lordosis, causing an increase in thoracic kyphosis. The combination of increased tension in neck extensors and flexion of the cervical spine creates regions of stress in the neck, resulting in postural pain syndromes [9]. Adopting this sitting posture during office tasks causes contraction of the chest muscles, limiting their mobility and thus disturbing humeroscapular rhythm [4].

It is worth noting that the head accounts for approximately one-seventh of the total body weight, and that the typical location of computer display units contributes to anterior head translation, causing an additional challenge for the muscles of the neck, shoulders and upper limbs.

This may result in increased muscle tension, soft tissue shortening, weakness of the ligamentous structures, tendonitis, degenerative changes, and pressure on the nerves originating from the cervical spine $[10,11]$.

Ming [10] cites additional reasons for the development of neck pain syndromes and shoulder pain in people performing office tasks: repetition of movements, awkward or uncomfortably positioned upper limbs associated with an increased flexion or deviation of the hand, lack of workplace adjustments (no seat height adjustment, poor lighting) and individual predispositions arising from gender, age, weight, habits, the existence of possible deformation $[10,11,12,13]$.

The research of Jung-Ho complements these studies, emphasizing the correlation of forward head posture and balance disturbances in office workers [2].

Effects of sitting posture on the lumbar spine. A sedentary lifestyle is widely recognized as one of the risk factors for low back pain and many authors see long-term effects of overloading these anatomical structures $[4,14]$.
Table 1. Consequences of disturbed head position while sitting

\begin{tabular}{llll}
\hline Author & \multicolumn{1}{c}{ Group size } & Type of study & \multicolumn{1}{c}{ Consequences } \\
\hline $\begin{array}{l}\text { Fernandes- } \\
\text { de-Las- } \\
\text { Penans [6] }\end{array}$ & $\begin{array}{l}\text { 20 people } \\
\text { with chronic } \\
\text { headaches 20 } \\
\text { people in the } \\
\text { control group }\end{array}$ & $\begin{array}{l}\text { Palpation, } \\
\text { scales VAS }\end{array}$ & $\begin{array}{l}\text { Active trigger points in the area of } \\
\text { sub occipital muscles contributing } \\
\text { to headache }\end{array}$ \\
\hline Szeto [7] & $\begin{array}{l}73 \text { office } \\
\text { workers }\end{array}$ & EMG & $\begin{array}{l}\text { Upper cross syndrome } \\
\text { characterized by deep cervical } \\
\text { flexors weakness and increased } \\
\text { tension in the pectoral and upper } \\
\text { trapezius muscles }\end{array}$ \\
& $\begin{array}{l}\text { 20 people } \\
\text { without } \\
\text { symptoms }\end{array}$ & EMG & $\begin{array}{l}\text { Increases tension in neck extensors } \\
\text { and flexion of the cervical spine } \\
\text { creates regions of stress in the } \\
\text { neck, resulting in postural pain } \\
\text { syndroms }\end{array}$ \\
\hline Caneiro [9] & $\begin{array}{l}30 \text { office } \\
\text { workers and } \\
30 \text { control } \\
\text { subjects }\end{array}$ & $\begin{array}{l}\text { Computerized } \\
\text { dynamic } \\
\text { posturography }\end{array}$ & $\begin{array}{l}\text { balance disturbances } \\
\text { Jung-Ho [2] }\end{array}$ \\
\hline
\end{tabular}

Slump posture eliminates the correct curvature of the spine and increases pressure on the intervertebral discs, in which the front portion is compressed and the back stretched. This situation leads to a backward shift of the nucleus pulposus, which over time can lead to the development of disc herniation. Typically, selected seats are those with a backrest. Morla and Bradl showed significant differences between seats with and without backrests. Their results confirm that the seat without back support preserves lumbar lordosis and is accompanied by reduced muscle tension in the lumbar region. In contrast, a seatback predisposes to kyphotic position, flattening the lumbar lordosis and contributes to posterior pelvic tilt. [15]. The consequence of increased posterior pelvis tilt are decreased activation of the multifidius and erector spinae (longissimus) muscles, as well as a weakness of the abdominal and buttock muscles [15]. Rasouli [16] confirms the relationship between the slump postion and low activity of the transversus abdominis muscle [16]. This position also has consequences for the diaphragm, as it reduces the amplitude of its movement and activates the accessory inspiratory muscles of the upper-thoracic respiratory tract [4]. Sitting in a slump position with decreased lumbar lordosis increases the risk of reduced mobility in the shoulder girdle. This was confirmed by the research of Kanalayanaphotporna [17]. Comparing the most common sitting positions, he showed that the greatest range of motion limitation in the shoulder joint occurs when there is complete loss of lumbar lordosis. A change in the setting of the lumbar spine position in a sitting position is significantly related to changes in the shoulder joint mobility in all directions [17].

The research by Lewis [18] supported this notion while examining changes in thoracic kyphosis. He demonstrated that a reduction of even a few degrees of thoracic kyphosis can increase the painless range of motion in the shoulder. Burnet, however, studying the effect of lumbar flexion on the cervical-thoracic spine, concluded that there is no correlation between lumbar spine flexion and tension in the cervicothoracic musculature [19].

Effect of sitting posture on the respiratory system and mobility of the chest and diaphragm.

Body posture has been shown to affect respiratory function and mobility of the chest and diaphragm [7, 20,21]. Many 
reports indicate that the synchronized interaction of the muscles of the neck, trunk, abdomen, shoulder and pelvic girdle may be crucial for breathing activity.

Lee estimated the impact of different sitting positions, such as: neutral, slump, with side-shift of the chest and with the rotation and half-rotation of multi-directional changes in the chest during breathing [20]. The results suggest that even subtle differences in sitting posture influence both the 3-dimensional mobility of the chest and tidal volume. Lee concluded that a slumped position has the greatest impact on the variables characterizing respiration. Lee further confirmed the flexibility of the respiratory system which enables adaptation to changes in body position and stimulation of the appropriate muscles to work in order to maintain the normal function of the respiratory system. This relationship was most clearly observed with healthy subjects without restrictions on the mobility of the chest. This is possible because of advanced mechanisms which adjust the respiratory apparatus to various conditions in which the body exists [20].

Kaneko and Horie measured the 3-dimensional breathing movement distances of the thorax and abdomen in healthy subjects in a sitting position. They observed that, compared to a standing position, sitting decreases the mobility of both the chest and abdomen [21]. The existence of such interactions was confirmed by Wang who evaluated the relationship between movements of the chest wall and diaphragm in healthy young people in a sitting position [22]. Similarly, Romei confirmed that body posture has a significant impact on the engagement of the chest and diaphragm during breathing [23]. He used an optoelectronic plethysmograph in a study with 34 participants. Each individual was tested in 5 positions: sitting without a backrest, with the backrest inclined at a sitting angle of about $80^{\circ}, 2$ reclining positions with the backrest at an angle of approximately $65^{\circ}$ and $40^{\circ}$, and lying down. The participants were asked to breathe naturally for 3 minutes in each position. Analysis of the results confirmed the principle that amplitude of respiratory movements on the thoracic tract decreased with a decreasing backrest angle. Respiratory rate, tidal volume and minute ventilation showed higher values in the sitting position without support [23]. Lin showed that the slump position when sitting results in a decrease in spirometric variables, compared to a position maintaining the physiological spine curvature [24].

The maintaining of spine curvature is also a condition for correct diaphragm activity. The slump posture impairs diaphragm breathing and increases upper respiratory tract breathing $[4,25]$. Whitelaw and Rimmer demonstrated that trunk rotation alters the activity of the intercostal, abdominal and paraspinal muscles. They observed that competition between respiratory and postural muscles depends on the sitting position (slump, rotated) and determines the breathing pattern $[26,27]$.

Correct sitting posture. Analysis of the literature on sitting posture demonstrates that it is the subject of regular and ongoing research. Most authors focus their attention on parts of the body which are at greatest risk of syndromes emerging from incorrect sitting positions, among others, pain syndromes of the lower or upper part of the spine, limitation of chest mobility, abnormal activity and overtension of softtissue structures, etc. Analysis has tended to be segmental with no holistic assessment of sitting posture, serving to underline the complexity of the problem. Research has not yet yielded a useful guide to choosing the right chair, or chairs suitable for specific occupations. There is also no widely agreed methodology for assessing seat quality.

The sitting position requires less energy than standing. Hence, we often sit to work and to rest, and sitting is often the privilege of rulers. Sitting posture changed into various forms, and with it developed the shape of the chairs and also the different types of backrest, seat, upholstery and chair sizes. New designs competed with each other in the aspects of size, price and attractive appearance. In the nineteenth century, Staffel, a German orthopedist, constructed a chair recognized as the precursor of modern designs. Although he emphasized the importance of lumbar support, he could not explain the reason for it $[14,28]$. in the 1980s, Majeske and Buchanan argued the need for a roll supporting the lumbar spine. They demonstrated that its use changes sitting posture and helps maintain lumbar lordosis, thus preventing lower back pain. Lumbar roll influences the anterial pelvis tilt and affects the physiological curvature of the cervical, thoracic and lumbar spine [29]. Lengsfeld also agreed with the need to support the lower part of the spine. Additionally, he highlighted the importance of the slope of the seat relative to the floor. In his study, he observed changes in lumbar lordosis in upright (vertical) and reclining positions. Chairs with adjustable backrest were shown to affect intersegment angles, particularly the L1-L2 and L4-L5, and were better able to maintain lumbar lordosis than chairs without a backrest [30]. Claus [31] and Scannell [32] found that sitting with the so-called 'long' lordosis in the lower section of the spine is the most correct, as it sets the spine in a physiological position. De Cervalho's research suggests that sitting with low back support maintains the correct angle between the vertebrae L5/S1, reducing tension and stretch of soft tissue, thereby preventing overloading of the intervertebral disc at L4/L5. According to De Cervalho, the natural position (physiological) reduces the risk of overloading and discomfort, while increased lumbar flexion predisposes the sitter to back pain syndrome [33, 34]. O'Sullivan, in collaboration with physiotherapists from Germany, England, the Netherlands and Ireland, looked at prevention of lumbar-sacral spine overloading while sitting. As a result, 2 main sitting postures were distinguished: 1) characterised by an extension in the lumbar and thoracic spine, and 2) by maintaining physiological lumbar lordosis and relaxation in the thoracic spine. The study showed that both positions influence the reduction of discomfort in the lower part of the spine $[35,36]$. Numerous other authors have recognized the need to maintain physiological lordosis while sitting [31, 32, 33, 34, 37, 38, 39]. Claus [31] and Scannell [32] showed that arterial pelvis tilt provides the least loading of the spine. This position of the pelvis ensures physiological curvature of the lower spine, since this reduces pressure on the intervertebral discs, and also tension in soft-tissue structures within the lower part of the body. It is not only the pelvis which determines the quality of sitting posture.

Many authors point out the unique role of head position $[4,40,41,42]$. Corlett emphasizes the role of setting the computer screen at eye level, as a condition for avoiding overloading the muscles of the neck and shoulder girdle $[43,44]$. Burgess-Limerick studied cervical flexion when setting the monitor at eye level and inclined at an angle of $30^{\circ}$ degrees. This setting was shown to reduce hyperextension in 
the $\mathrm{C} 0-\mathrm{C} 1$ and $\mathrm{C} 1-\mathrm{C} 2$ joints, which has a positive effect on the cervical spine [40]. The afore-mentioned monitor angle has also been documented in the literature review by Harrison [41]. In turn, Ming indicates optimal the screen position to be $15^{\circ}$ degrees below the horizontal line of the eye (angle between ear and eye) $[10,11]$. Maintaining physiological thoracic kyphosis while sitting can reduce global flexion of the cervical spine, and thus the forward translation of the head. The relationship is confirmed by a reduction of tension in neck extensor muscles [9].

The setting of the upper limbs during the performance of tasks such as typing, handling the mouse, manually filing notes, etc., is also important. During the performance of these activities, the hands should have full freedom of movement, while the forearms and elbows should be supported by armrests $[4,43,44]$. The location of the upper limbs during different activities is as important as the position of the head. The angle between the arm and forearm during typing, for example, should be $100^{\circ}$ (obtuse angle) $[4,10]$. These recommendations are important even in the prevention of carpal tunnel syndrome and disorders of the shoulder girdle.

During long hours of work in a sitting position, the correct positioning of the joints of the lower extremities is a further important consideration. Leavitt recommended placement of the feet in a slight flexion $\left(0-15^{\circ}\right)$ and support for the props or the floor [14]. Other authors have emphasized the potential for dorsi and plantar flexion movement to activate the muscle pump and improve circulation $[4,43$, 44]. Maintaining a small knee flexion and hip joint flexion of $95-100^{\circ}$ is recommended. This position provides anterior pelvis tilt, which can be further magnified by sliding one foot further forward [14, 43, 45].

In addition to correct body posture when working with display equipment, both Ming [10] and Morl [15] highlight the need for short breaks to enlarge the neck muscles, together with relaxation techniques and regular exercise to prevent increased muscle tension and overloading of the musculoskeletal system.

\section{CONCLUSIONS}

The majority of the authors cited above agree that:

1) incorrect sitting posture contributes to many disorders, especially in the cervical and lumbar spine; it also determines respiratory system functioning;

2) maintaining physiological spine curvature when sitting is crucial in the biomechanics of the sitting position; head posture and position of the pelvis are particularly important;

3) it is necessary to raise awareness of work-related hazards and to introduce education regarding proper sitting posture.

\section{REFERENCES}

1. Chaitow L, Fritz S. Masaż leczniczy. Badanie i leczenie mięśniowopowięziowych punktów spustowych. Elsevier Urban and Partner, Wrocław, 2010.

2. Jung-Ho K, Rea-Young P, Su-Jin L, Ja-Young K, Seo-Ra Y, Kwang-Ik $\mathrm{J}$. The effect of the forward head posture on postural balance in long time computer based worker. Ann Rehabil Med. 2012; 36(1): 98-104.

3. Dunstan DW, Howard B, Healy GN, Owen N. Too much sitting - A health hazard. Diabetes Res Clin Pract. 2012; 97(3): 368-379.
4. Groszek M, Babula G, Nagraba Ł, Stolarczyk A, Mitek T. Zagrożenia powstające w wyniku niewłaściwej postawy siedzącej. Artoskopia i Chirurgia Stawów. 2011; 7(3-4): 50-61.

5. Harrison DE, Harrison DD, Janik TJ, Wiliam JE, Cailliet R, Normand M. Comparison of axial and flexural stresses in lordosis and three buckled configurations of the cervical spine. Clin Bimech, 2001; 16(4): 276-284.

6. Fernandes-de-Las-Penas C, Alonso-Blanco C, Cuadrado ML, Pareja JA. Trigger points in the suboccipital muscles and forward head posture in tension-type headache. Headache. 2006; 43(3): 225-230.

7. Szeto GPY, Straker LM, O'Sullivan PB. Neck-shoulder muscle activity in general and task-specific resting postures of symptomatic computer users with chronic neck pain. Man Ther. 2009; 14(3): 338-45.

8. Page P, Frank CC, Lardner R. Assessment and Treatment of Muscle Imbalance: The Janda Approach. Human Kinetics. Champaign, IL. 2010.

9. Caneiro JP, O’Sullivan P, Burnett A, Barach A, O'Neil D, Tveit O, Olafsdottir K. The influence of different sitting postures on head/neck posture and muscle activity. Man Ther. 2010; 15: 54-60.

10. Ming Z, Narhi M, Siivola J. Neck and shoulder pain related to computer use. Pathophysiol. 2004; 11(1): 51-56.

11. Ming Z, Zaproudina. Computer use related upper limb musculoskeletal disorders. Pathophysiol. 2003; 9(3): 155-160.

12. O'Sullivan K, O’Dea P, Dankaerts W, O'Sullivan P, Clifford A, O'Sullivan L. Neutral lumbar spine sitting posture in pain-free subjects. Man Ther. 2010; 15(6): 557-61.

13. Dunk NM, Callaghan JP. Gender-based differences in postural responses to seated exposures. Clin Biomech. 2005; 20(10):1101-10.

14. Leavitt SB, Steward B. Sitting smarter. Health Facil Manage.1995; 8(6): 22-28.

15. Morl F, Bradl I. Lumbar posture and muscular activity while sitting during office work. J Electromyogr Kinesiol. 2012; 23(2): 1-6.

16. Rasouli O, Arab AM, Amiri M, Jaberzadeh S. Ultrasound measurement of deep abdominal muscle activity in sitting positions with different stability levels in subjects with and without chronic low back pain. Man Ther. 2011; 16(4): 388-393.

17. Kanalayanaphotporn R. Changes in sitting posture affect shoulder range of motion. Bodyw Mov Ther. 2013; 1-5.

18. Lewis JS, Wright C, Green A. Subacromial impingement syndrome: the effect of changing posture on shoulder range of movement. J. Orthop Sports Phys Ther. 2005; 36(2): 72-87.

19. Burnett A, O'Sullivan P, Caneiro JP, Krug R, Bochmann F, Helgestad GW. An examination of the flexion-relaxation phenomenon in the cervical spine in lumbo-pelvic sitting. Electromyogr Kinesiol. 2009; 19(4): 229-236.

20. Lee LJ, Chang AT, Cooppieters MW. Changes in sitting posture induce multiplanar changes in chest wall shape and motion with breathing. Respir Physiol Neurobiol. 2010; 170(3): 236-245.

21. Kaneko H, Horie J. Breathing movements of the chest and abdominal wall in healthy subjects. Respir Care 2012; 57(9):1442-1451.

22. Wang HK, Lu TW, Liing RJ, Shin TT, Chen SC, Lin KH. Relationship between chest wall motion and diaphragmatic excursion in healthy adults in supine position. J Formos Med Assoc. 2009; 108(7): 577-586.

23. Romei M, Lo Mauro A, D’Angelo MG, Turconi AC, Bresolin N, Pedotti A, Aliverti A. Effects of gender and posture on thoraco-abdominal kinematics during quite breathing in healthy adults. Respir Physiol Neurobiol. 2010; 172(3): 184-191.

24. Lin F, Parthasarathy S, Taylor J, Pucci D, Hendrix R, Makhsous M. Effect of Different Sitting Postures on Lung Capacity, Expiratory Flow, and Lumbar Lordosis; Arch Phys Med Rehabil. 2006; 87(4): 504-509.

25. Hodges P, Heinjnen I, Gandevia SC. Postural activity of the diaphragm is reduced in humans when respiratory demand increases. J Physiol. 2001; 537: 999-1008.

26. Whitelaw WA, Ford GT, Rimmer KP, De Troyer A. Intercostal muscles are used during rotation of the thorax in humans. J Appl Physiol. 1992; 72(5): 1940-1944.

27. Rimmer KP, Ford GT, Whitelaw WA. Interaction between postural and respiratory control of human intercostal muscles. J Appl Physiol. 1995; 79(5): 1556-1561.

28. Staffel F. Zur Hygiene des citizens. Zbl F Allg Gesundheitspflege 1884; 3: 403-21.

29. Majeske C, Buchanan C. Quantitative description of two sitting postures- with and without a lumbar support pillow. Physical Therapy 1984; 64(10): 1531-1535.

30. Lengsfeld M., Frank A., van Deursen L. Lumbar spine curvature during office chair sitting. Med Eng Phys. 2000; 22(9): 665-669. 
31. Claus AP, Hides JA, Morseley GL, Hodges PW. Is 'ideal' sitting posture real? Measurement of spinal curves in four sitting postures. Man Ther. 2009; 14(4): 404-408.

32. Scannell JP, McGill SM. Lumbar posture - should it, and can it, be modified? A study of passive tissue stiffness and lumbar position during activities of daily living. PhysTher. 2003; 83(10): 907-917.

33. De Carvalho DE, Soave D, Ross K, Callaghan JP. Lumbar spine and pelvic posture between standing and sitting: A radiologic investigation including reliability and repeatability of the lumbar lordosis measure. J Manipulative Physiol Ther. 2010; 33(1): 48-55.

34. De Carvalho DE, Callaghan JP. Influence of automobile seat lumbar support prominence on spine and pelvic postures A radiological investigation. J Manipulative Physiol Ther. 2011; 43(5): 876-882.

35. O'Sullivan K, O'Sullivan P, O'Sullivan L, Dankaerts W. What do physiotherapists consider to be the best sitting spinal posture? Manual Therapy 2012; 17(5): 432-437.

36. O'Sullivan K, O’Keeffe M, O'Sullivan L, O'Sullivan P, Dankaerts W. Perceptions of sitting posture among members of the community,both with and without non-specific chronic low back pain. Man Ther. 2013; 18(6): 551-556.
37. Dankaerts W, O'Sullivan PB, Burnett A, Straker LM. Differences in sitting postures are associated with non-specific chronic low back pain disorders when subclassified. Spine 2006; 31(6): 698-704.

38. Womersley L, May S. Sitting posture of subjects with postural backache. J Manipulative Physiol Ther. 2006; 29(3): 213-8.

39. Pynt J, Mackey MG, Higgs J. Kyphosed seated postures: extending concepts of postural health beyond the office. J Occup Rehabil. 2008; 18(1): 35-45.

40. Burgess-Limerick R, Plooy A, Fraser K. The influence of computer monitor height on head and neck posture. Industrial Ergonomics 1999; 23: 171-179.

41. Harrison DD, Harrison SO, Croft AC, Harrison DE, Troyanovitch SJ. Sitting biomechanics part I: review of the Literature. J Manipulative Physiol Ther. 1999; 22(9): 594-609.

42. Schmidt S, Amereller M, Franz M, Kaiser R, Schwirtz A. A literature review on optimum and preferred joinr angles in automotive sitting posture. App Ergon. 2013; 45(2): 1-14.

43. Corlett EN. Ergonomics and sitting at work. Work. 2009; 34(2): 235-238.

44. Corlett EN. Sitting as a hazard. Safety Science 2008; 46: 815-821.

45. Tilley AR, Dreyfuss H. The Measure of Man and Woman. Human Factors in Design, 2. Aufl Wiley, New York; 2002. 